\title{
Measures of criminal law regulation of environmental crimes in the Tyumen city
}

\author{
Victoria Lez'er ${ }^{1 *}$, Vyacheslav Sevalnev ${ }^{2}$, Ekaterina Cherepanova $^{2}$, and Valeriy Zhabskiy ${ }^{3}$ \\ ${ }^{1}$ Tyumen Industrial University, Volodarskogo str., 38, Tyumen, 625000, Russia \\ ${ }^{2}$ Institute of Legislation and Comparative Law under the Government of the Russian Federation, \\ Cheremushkinskaya str., 34, Moscow, 117218, Russia \\ ${ }^{3}$ Moscow University of the Ministry of Internal Affairs of the Russian Federation named after V.Y. \\ Kikot, Academician Volgin str., 12, Moscow, 117437, Russia
}

\begin{abstract}
The aim of the article is to analyze the measures of criminallegal regulation of environmental crimes in Russia, using the example of the city of Tyumen, based on a study of official statistics, current criminal and other legislation, and general theoretical provisions. In the process of writing the article, following research methods were used: formally legal, historical and legal, comparative legal method, analysis, comparison, statistical method and others. The authors provide official statistics regarding the criminal situation in Tyumen in 2015-2019 on environmental crimes.
\end{abstract}

\section{Introduction}

According to the content of Art. 58 of the Constitution of the Russian Federation, every citizen is obliged to preserve nature and environment, take care of natural resources. Article 11 of the Federal Law dated 12.01.2002 No. 7 "On Environmental Protection" (last revised on 01.01.2020) states that every citizen has the right to favorable environment, to protect it from the negative impact caused by economic and other activities, natural and man-made emergencies, to have reliable information about the state of environment and to have compensation for environmental damage.

Environmental crime is a complex set of crimes against the environment, i.e. socially dangerous, guilty, unlawful, harmful to the environment and human health acts prohibited and punishable in accordance with criminal law, encroaching on public relations to protect the natural environment and the rational use of natural resources, including ensuring the environmental safety of individuals, people, society, nation and sustainable development of the state.

The Criminal Code of the Russian Federation [Criminal Code of the Russian Federation, 1996, (as amended on 12/27/2019).] (Hereinafter - the Criminal Code of the Russian Federation) provides for Chapter 26 "Environmental crimes", including art. 246262 of the Criminal Code of the Russian Federation (18 articles), which defines intentional or reckless socially dangerous acts that infringe on environmental relations established in

"Corresponding author: a.copytowa@yandex.ru 
Russia, environmental safety of society and the state that causes harm or poses a threat to the environment, people and other law enforcement interests. $\neg$

In the scientific literature, enough definitions of the concept of "environmental crimes" are given, which cannot be said about the normative consolidation of this concept.

In the legal literature regarding the classification of environmental crimes, many scientific approaches are proposed, which causes heated debates.

So, O.L. Dubovik proposes to classify environmental crimes into two groups, based on the consolidation of criminal acts in the Criminal Code of the Russian Federation: 1) crimes with responsibility provided for in Chapter 26 (Articles 246-262 of the Criminal Code of the Russian Federation); 2) environmental crimes with responsibility placed in other chapters (for example, Article 215 (Chapter 24), Articles 236, 237, 243, 245 (Chapter 25)) [Environmental Law in Questions and Answers, 2016, 26].

V.V. Sverchkov, based on the generally accepted criterion, which is the direct object of the crime, offers to distinguish following groups of environmental crimes: 1) crimes expressed in violation of the rules of general environmental safety (Articles 246-248 of the Criminal Code of the Russian Federation); 2) crimes in relation to the basic objects of the natural environment, i.e. water, atmosphere, soil, bowels, etc. (Articles 250-255 of the Criminal Code of the Russian Federation); 3) crimes in relation to fish stocks, flora and fauna (Articles 249, 256-262 of the Criminal Code of the Russian Federation).

It should also be noted that in the legal literature there are scientific approaches regarding the allocation of socially dangerous acts that are associated with causing harm to the environment and are contained in other chapters of the Criminal Code of the Russian Federation.

So, V.P. Kashepov considers socially dangerous acts, which are provided for in other chapters of the Criminal Code of the Russian Federation, namely, in chapter 24 "Crimes against public safety" (Article 215 of the Criminal Code of the Russian Federation "Violation of safety rules at nuclear energy facilities", as a crime involving environmental harm)". And others), in chapter 25" Crimes against public health and public morality "(Article 237 of the Criminal Code of the Russian Federation "Concealment of information about circumstances that endanger human life or health", etc.), in chapter 34 "Crimes against peace" and safety of mankind "(Article 358 of the Criminal Code "Ecocide").

In order to uniformly apply and interpret the norms of federal law in the course of a preliminary investigation and consideration of cases by courts for committing environmental crimes, as well as for the unity of judicial practice, the Plenum of the Supreme Court of the Russian Federation, guided by Art. 126 of the Constitution of the Russian Federation, adopted resolution No. 21 dated 10/18/2012 "On the application by the courts of legislation on liability for violations in the field of environmental protection and nature management" and at the same time draws the attention of courts and other law enforcement authorities to features of the criminal law characteristics and qualifications of environmental crimes.

The problem and purpose of the study: analysis of measures of criminal law regulation and prevention of environmental crimes on the example of the city of Tyumen.

The authors assume that environmental crimes are usually

1. consequence of violations of laws and other regulations by individual officials;

2. underestimation of measures of public influence, etc., and the situation is complicated by the lack or inefficiency of environmental supervision, inaction of many regulatory bodies. For example, effectiveness of all activities of forest control bodies is several times lower than effectiveness of one-time operations carried out by the internal affairs bodies and the border service.

3. Growth of environmental crimes also occurs due to the imperfection of legislation on liability for environmental offenses (a lot of reference norms, inconsistencies between acts 
and norms, insufficiently clear formulations of legal norms).

\section{Methods}

\section{Statistics method}

Crime in the field of ecology is characterized by high latency - only a small part of the crimes actually committed is reflected in the statistics. At the same time, not only the hidden, but also the covert part of such crimes is high: the total number of criminal cases initiated annually on the facts of identified environmental crimes clearly does not correspond to the number of reports about them known to law enforcement agencies.

2. Logical method of analysis and synthesis of factors and causes of environmental crime

In the causal complex of environmental crime interact numerous and diverse circumstances that need to be twisted and classified.

3. Formal legal method: distinction between environmental crimes and administrative offenses

The authors propose to pay attention to the presence of another unresolved problem, which consists in distinguishing between environmental crimes and administrative offenses related to environmental damage. The Code of the Russian Federation on Administrative Offenses, 2001 (hereinafter - the Code of Administrative Offenses of the Russian Federation) provides for Chapter 8 "Administrative Offenses in the Field of Environmental Protection and Nature Management", which includes more than 40 articles prohibiting acts that directly cause harm to various environmental objects (for example, article 8.6. of Administrative Code of the Russian Federation "Damage to the land" and the same article of article 254 of the Criminal Code of the Russian Federation). Hence the difficulty in determining by law enforcement agencies and the court the degree of public danger of similar socially dangerous acts. In one case they are considered as crimes, and in another case they are considered as an administrative offense. As a rule, errors arise in distinguishing between environmental crimes and administrative offenses, their qualifications, taking into account a whole range of signs and conditions contained in the relevant regulatory legal acts.

4. Comparative legal method of measures to prevent and reduce the number of environmental crimes.

\section{Results}

1. Statistics of environmental crimes in Tyumen in 2015-2019

According to official statistics, in 2017, 2160.1 thousand crimes were registered in Russia, of where 23.7 thousand were environmental crimes (the share of crimes in this category was $1.1 \%$ ) [Crime State in Russia, 2017, www].

Detection of environmental crimes in the Russian Federation over the past 5 years averages $85.4 \%$.

Environmental crimes include water pollution (Article 250), air pollution (Article 251), land damage (Article 254), only 19 criminal cases were filed $(0.22 \%$ ) in 2014, and only 23 cases in 2015 ( $0,19 \%$ of all recorded environmental crimes).

It is noteworthy that there is a sharp discrepancy between the number of criminal cases initiated and the environmental crimes actually committed, as well as the number of convicted persons brought to justice for them.

So, for example, in 2015, 62 persons were found guilty of illegal extraction of aquatic animals and plants (Article 256, Part 1.2), and 36 of them were convicted. Analysis of the 
practice of applying the norms of the Criminal Code of the Russian Federation in 20122013 showed: mainly 3 articles are applied on liability for the illegal seizure of natural resources (Articles 256, 258, 260 of the Criminal Code of the Russian Federation). It makes $97 \%$ of crimes in general structure of environmental crime.

So, of the total number of registered environmental crimes in 2015, these types of crimes are respectively: $44.2 \% ; 7.8 \% ; 45.7 \%$. Crimes related to environmental pollution (Art. 250,251.252 of the Criminal Code of the Russian Federation) make up only 2\% of the total number of registered environmental crimes, less than $1 \%$ - all other crimes.

As an example of the dynamics of environmental crimes in Tyumen, we give the data in the table 1 .

Table 1. Environmental crimes in Tyumen in 2018 and 2019

\begin{tabular}{|c|c|c|}
\hline $\begin{array}{l}2019 \text { YEAR } \\
\text { A total of } 329 \\
\text { criminal cases }\end{array}$ & Environmental crimes in Tyumen & $\begin{array}{l}2018 \text { YEAR } \\
\text { A total of } 134 \\
\text { criminal cases }\end{array}$ \\
\hline 254 criminal cases & $\begin{array}{c}\text { Article } 260 \text { of the Criminal Code of the } \\
\text { Russian Federation "Illegal felling of forest } \\
\text { stands". }\end{array}$ & 86 criminal cases \\
\hline 9 criminal cases & $\begin{array}{l}\text { "Illegal extraction of aquatic biological } \\
\text { resources" (Article } 256 \text { of the Criminal Code } \\
\text { of the Russian Federation), }\end{array}$ & 3 criminal cases \\
\hline 7 criminal cases & $\begin{array}{c}\text { destruction or damage of forest stands (Article } \\
261 \text { of the Criminal Code of the Russian } \\
\text { Federation) }\end{array}$ & 5 criminal cases \\
\hline 4 criminal cases & $\begin{array}{l}\text { illegal extraction or trafficking of especially } \\
\text { valuable wild animals and aquatic biological } \\
\text { resources listed in the Red Book of the Russian } \\
\text { Federation (Article } 258.1 \text { of the Criminal Code } \\
\text { of the Russian Federation). }\end{array}$ & 2 criminal cases \\
\hline 4 criminal cases & $\begin{array}{l}\text { Article } 191.1 \text { of the Criminal Code of the } \\
\text { Russian Federation ("Acquisition, storage, } \\
\text { transportation, processing for marketing or sale } \\
\text { of knowingly illegally harvested wood") }\end{array}$ & 6 criminal cases \\
\hline 3 criminal cases & $\begin{array}{l}\text { Article } 254 \text { of the Criminal Code of the } \\
\text { Russian Federation ("Land Damage") }\end{array}$ & 7 criminal cases \\
\hline 2 criminal cases & $\begin{array}{l}\text { Article } 250 \text { of the Criminal Code of the } \\
\text { Russian Federation ("Water Pollution") }\end{array}$ & 10 criminal cases \\
\hline $\begin{array}{c}254 \text { cases were } \\
\text { opened, } 45 \text { of them } \\
\text { are criminal cases } \\
\text { Causing damage - } 132 \\
\text { million rubles }\end{array}$ & & $\begin{array}{l}\text { Causing damage - } \\
\text { more than } 11.9 \\
\text { million rubles. }\end{array}$ \\
\hline $\begin{array}{c}108 \text { criminal cases } \\
\text { examined in court } \\
\text { COMPENSATION } \\
\text { FOR DAMAGE - } \\
\text { 10.8 MILLION } \\
\text { RUBLES, } \\
\text { CLAIMS ARE } \\
\text { FILED FOR A } \\
\text { TOTAL OF OVER } 43 \\
\text { MILLION RUBLES }\end{array}$ & & $\begin{array}{l}90 \text { criminal cases } \\
\text { examined in court } \\
\text { Compensation for } \\
\text { damages in the } \\
\text { amount of over } 2.5 \\
\text { million rubles. }\end{array}$ \\
\hline
\end{tabular}

Statistics show that the number of environmental crimes in Tyumen in 2019 has tripled compared to 2018. This initiates the intensification of measures to counter environmental crimes and offenses.

2. The authors analyzed measures to identify and fight illegal encroachments in the field of ecology by law enforcement agencies of the region with the coordinating role of the prosecutor's office. 
In 2017 and the expired period of 2018, in order to increase the effectiveness of activities to identify and prevent violations of environmental protection rules during work, the Investigative Department took part in 2 interdepartmental meetings of the Tyumen Environmental Prosecutor with representatives of the Department of Subsoil Use and Ecology of the Tyumen Region and the Forestry Department of the Tyumen Region, Office of Rosprirodnadzor for the Tyumen Region and the North-Ural Department of Rostekhnadzor, which adopted an additional complex set of measures aimed at identifying these crimes. So, in 2017, the Investigation Department received 7 reports of environmental crimes, according to the results of which 7 criminal cases were initiated. For the expired period of 2018, 4 reports of environmental crimes were registered, and according to the results of their consideration, criminal cases were initiated under Art. 260 of the Criminal Code, and under Part 2 of Art. 247 of the Criminal Code.

A positive example of cooperation in the identification and investigation of criminal environmental cases is a criminal case initiated by the Tyumen inter-district investigation department under part 2 of article 247 of the Criminal Code of the Russian Federation, during the investigation of which it was established that the head of the commercial enterprise organized the discharge of liquid wastes of milk production related to the fourth hazard class, which caused environmental pollution and also damaged the soil in the amount of over 2 million 600 thousand rubles. During the preliminary investigation in the criminal case, the cause is fully compensated and it is sent to the court. In 2019, a criminal case was opened in the production of JI for the Central AO of Tyumen, initiated on the basis of the elements of a crime under Part 2 of Art. 247 of the Criminal Code of the Russian Federation, on the fact of discharge into the soil on a site located on the left bank of the Tura River waste that, in accordance with the Federal Classification Catalog of Waste, belongs to the first hazard class of waste, which caused environmental pollution and caused damage in the amount of over 130 million rubles.

The work of the investigative units of the Investigative Department for the identification, disclosure and investigation of environmental crimes is under the constant supervision of the leadership of the Investigative Department.

\section{Discussion: environmental crime prevention}

Activities of subjects for prevention of crimes in the field of ecology are designed to purposefully influence the objective reasons and conditions for committing environmental crimes, criminal situations in certain regions that provoke criminal attacks, negative personal characteristics, as well as antisocial behavior of people who committed environmental crimes.

1. Important subjects of prevention of environmental crimes are the bodies of state management of natural resources and environmental protection. Numerous state environmental authorities are involved in this, including various inspections, control and supervision services for nature protection. On the territory of the Tyumen region, organizations monitoring compliance with environmental legislation include: the Tyumen Interdistrict Environmental Prosecutor's Office; North Ural Interregional Department of the Federal Service for Supervision of Natural Resources Management (Rosprirodnadzor); Department of subsoil use and ecology of the Tyumen region. Their preventive activities would be more effective provided that their financing was improved, adequate material, technical, personnel and other resources were provided, and social and legal protection of employees was strengthened.

2. Specialized inter-district environmental prosecutor's offices occupy currently special place in the system of bodies fighting environmental crime. Their experience should be more effective in monitoring the implementation of environmental legislation. It is the 
activity that is able to neutralize the negative consequences, errors and omissions in the work of environmental authorities, violations of environmental laws by executive bodies and local authorities.

3. It should be noted that the success of the fight against crime in the environmental sphere is largely determined by the consistency and effectiveness of law enforcement agencies, their determination and offensiveness in achieving the goal.

4. One of the important conditions for increasing the effectiveness of the fight against environmental crimes is the continuous improvement of the legal framework for environmental protection. Of great importance in this regard is the further improvement of environmental legislation.

\section{Conclusion}

Specifics of the fight against environmental crime lies in the need to constantly ensure active and clearly coordinated actions by all environmental, control and law enforcement agencies to strengthen environmental law and order in Russia. Therefore, it is important that the authorities and administrations at all levels fulfill this coordinating function fully and effectively.

The formation of a new ecological and legal worldview is one of the important factors in the fight against crimes in the field of ecology. Environmental education and formation of environmental culture contribute to the effective prevention of environmental crime.

Environmental legislation is both product and the main form of consolidation of state environmental policy.

\section{References}

1. U. Uzar, Journal of Cleaner Production 255, 120287 (2020) DOI: $10.1016 /$ j.jclepro.2020.120287

2. V.A. Lez'Er, N.A. Semeryanova, A.V. Kopytova, MATEC Web of Conferences, 239, 04027 (2018) DOI: 10.1051/matecconf/201823904027

3. S.A. Bogolyubov, Journal of Russian Law, 4, 105-119. (2019) DOI: 10.12737/art_2019_4_9

4. C. Mombeuil, Journal of Cleaner Production 254, 120153 (2020) DOI: $10.1016 /$ j.jclepro.2020.120153

5. D.O. Sivakov Journal of Russian Law, 10, 136-144. (2019) DOI: 10.12737/jrl.2019.10.11

6. O.A. Zaitsev, Journal of Foreign Legislation and Comparative Law, 4, p.42-57. (2019) DOI: $10.12737 /$ jflcl.2019.4.

7. J. Laufs, H. Borrion, B. Bradford, Sustainable Cities and Society 55, 102023 (2020) DOI: $10.1016 /$ j.scs.2020.102023

8. M.J. Lynch, P.B. Stretesky, M.A. Long, Capitalism, Nature, Socialism 31(1), 107-122 (2020) DOI: 10.1080/10455752.2018.1545241

9. V.O. Belonosov, I.V. Chernysheva Russian criminal process (Dashkov \& Co., BusinessVolga, Moscow, 2013)

10. O. L. Dubovik, L. N. Choltyan Environmental law in questions and answers. (Moscow, Prospect, 2016)

11. V.N. Zhadan, Young scientist. 5, 515-519 (2013) 
12. D. Izvin, V. Lez'Er, A. Kopytova, MATEC Web of Conferences, 170, 01065 (2018) DOI: $10.1051 /$ matecconf $/ 201817001065$

13. A. Kopytova, MATEC Web of Conferences 106, 08056 (2017) DOI: 10.1051/matecconf/201710608056

14. Z.A. Umirbaeva, Russian investigator. 10, 17-19 (2010)

15. V. Lez'Er, N. Semerianova, A. Kopytova, Y. Truntsevsky, E3S Web of Conferences 110, 02093 (2019) DOI: 10.1051/e3sconf/201911002093

16. M.S. Abdul Samad, P. Mohan, G.K. Varghese, I.K. Shah, B.J. Alappat, Environmental Forensics 21(1), 37-47 (2020) DOI: 10.1080/15275922.2019.1694094

17. V.N. Zhadan, Young scientist. 4, 387-393 (2013)

18. A.V. Kopytova, N.S. Zotkina, I.G. Reshetnikova, MATEC Web of Conferences 239, 04012 (2018) DOI: 10.1051/matecconf/201823904012

19. M. Yu. Kondratiev, Theory and practice of forensics. 3(15), 80-81 (2009)

20. V.G. Pushkarev Jurisprudence and law enforcement practice. 1(11), 40-45 (2010)

21. N. Semeryanova, O. Fedorenko, A. Kopytova, MATEC Web of Conferences, 239, 04013 (2018) DOI: 10.1051/matecconf/201823904013

22. Yu.V. Popov, Socio-economic phenomena and processes. 6 (22) 213-215 (2016)

23. E. Velieva, Y. Veliev, IOP Conference Series: Earth and Environmental Science 403(1), 012209 (2019) DOI: 10.1088/1755-1315/403/1/012209

24. D. Earnhart, S. Rousseau, International Review of Law and Economics, 60, 105857 (2019) DOI: 10.1016/j.irle.2019.105857 